\title{
Productivity and Sensory Quality of Arabica Coffee in Response to Pruning Type 'Esqueletamento'
}

\author{
Denis Henrique Silva Nadaleti ${ }^{1}$, Diego Júnior Martins Vilela ${ }^{1}$, Gladyston Rodrigues Carvalho ${ }^{2}$, \\ José Marcos Angélico de Mendonça ${ }^{3}$, Cesar Elias Botelho ${ }^{2}$, Larissa Sousa Coelho ${ }^{1}$, Larissa de Oliveira Fassio ${ }^{2}$ \\ \& João Paulo Felicori Carvalho ${ }^{4}$ \\ ${ }^{1}$ Universidade Federal de Lavras, Lavras, Minas Gerais, Brazil \\ ${ }^{2}$ Empresa de Pesquisa Agropecuária de Minas Gerais, Belo Horizonte, Brazil \\ ${ }^{3}$ IFSULDEMINAS, Câmpus Muzambinho, Muzambinho, Minas Gerais, Brazil \\ ${ }^{4}$ Centro Universitário do Cerrado, Patrocínio, Minas Gerais, Brazil \\ Correspondence: Larissa Oliveira Fassio, Empresa de Pesquisa Agropecuária de Minas Gerais, Belo Horizonte, \\ Brazil.E-mail: larissafassio@yahoo.com.br
}

Received: March 7, 2018

doi:10.5539/jas.v10n6p207
Accepted: April 12, $2018 \quad$ Online Published: May 15, 2018

URL: https://doi.org/10.5539/jas.v10n6p207

The research is financed by Consórcio Pesquisa Café, FAPEMIG, CNPq, CAPES.

\begin{abstract}
Through the pruning type 'esqueletamento' it was developed a technology for the management of trees called "Zero Yield" in order to keep the size of the crop and eliminate the harvesting in a low yield season, which usually compromises the earnings of the coffee grower. With this technology, the harvest takes place every two years, always in years of high yield season. This technology is highly dependent on climate, and genotype. Given this, the objective of the study was to select genotypes of Coffea arabica L. responsive to pruning type 'esqueletamento', with high productivity and high potential for quality of drink for specialty coffee production. The experiment was deployed in the Coffee Sector at the Universidade Federal de Lavras (UFLA) in December 2005 and after six crops, it has undergone the pruning type 'esqueletamento' in August 2014. 20 genotypes were evaluated, being 18 progenies in $\mathrm{F}_{5}$ generation, derived from the cross between cultivars of the Catuai Group with coffees of germplasm Icatu and germplasm "Hibrido de Timor" and two commercial cultivars as witnesses. (Tupi IAC 1669-33 and Obatã IAC 1669-20). The following characteristics were evaluated: productivity (before and after pruning), vegetative vigor, the incidence of leaf rust, dull fruits, sieve No.16 and above, grain type mocha, aspect, and quality of drink. The genotypes 9 (H516-2-1-1-18-1-1), 12 (H516-2-1-1-18-1-4), 16 (H419-3-4-5-2-1-3), 18 (H419-3-4-5-2-1-5) and the cultivar Tupi IAC 1669-33 were responsive to the 'esqueletamento', with productivity after pruning higher than the maximum reached before the adoption of the pruning. All genotypes with the exception of Catucaí Amarelo 24/137 showed potential for the production of specialty coffees.
\end{abstract}

Keywords: Híbrido de Timor, specialty coffees, genotypes, aspect

\section{Introduction}

The Brazilian coffee production has undergone profound changes by adopting technologies to the entire production chain, as advances in mechanization, the use of irrigation, post-harvest innovations, the use of management of pruning in plantations, as well as the use of cultivars resistant to major pests and diseases.

One of the management practices responsible for the maintenance of the productive capacity of the plants, the pruning type 'esqueletamento' is widely used for the renovation of coffee plantations and/or recovery of plants affected by biotic and abiotic factors, especially those that cause severe defoliation, as in the case of leaf rust (main coffee disease), frost, hailstorms, among others.

Through the pruning type 'esqueletamento' it was developed a management system called "Zero Yield" whose purpose is to eliminate harvesting in low yield seasons (Japiassú et al., 2010). It is a recent Brazilian coffee 
production system and of great potential for the mountainous coffee-growing regions, but the answer in productivity is highly dependent on the climate in the year of pruning and genotyping.

The use of resistant cultivars is essential for the sustainability of coffee production, however, it is necessary that these cultivars present desirable agronomic characteristics, such as responsive to pruning, vigorous, large fruits and of good quality, compatible with the current demand of coffee production. Most improved cultivars, which are rust-resistant are descendants of "Hibrido de Timor", being that this germplasm has presented high variability for quality of drink (Carvalho et al., 2011), but good resistance to leaf rust when compared with the descendants of the germplasm Icatu, which generally have high vegetative vigor and high response to pruning.

Achieve high productivity has always been the main purpose of the coffee grower, primarily in Brazil, the biggest coffee producer. However, the high demand and financial recovery has stimulated quality coffees growers to produce more, with quality as a way to improve profitability in the production chain (Ferreira et al., 2012). Several factors are associated with this new concept of coffee production starting with the management system, the region of cultivation, chemical and physical quality of the soil, cultivar, quality of fruits and grains as well as economic, environmental and social sustainability of the production (Giomo \& Borém, 2011).

Thus, the objective of the study was to select genotypes of Coffea arabica L. responsive to 'esqueletamento', with high productivity and quality of drink coupled with the agronomic characteristics of interest.

\section{Method}

The experiment was conducted in the experimental area of the Coffee Sector at the Universidade Federal de Lavras, a reference in coffee research, located in Lavras, Minas Gerais - Brazil. The municipality is at 950 metres of altitude, $21^{\circ} 14^{\prime}$ South latitude and $44^{\circ} 57^{\prime}$ West longitude, with an average temperature of $21^{\circ} \mathrm{C}$ and average precipitation of $1115 \mathrm{~mm}$ in agricultural year of 2014/2015 and $20^{\circ} \mathrm{C}$ and $1442 \mathrm{~mm}$ for the year $2015 / 2016$ (INMET, 2017). The essay was deployed in December 2005, being adopted a $3.5 \times 0.70$ spacing, corresponding to a stand of 4,082 plants $^{-1} a^{-1}$.

20 genotypes were evaluated, including 18 progenies in $\mathrm{F}_{5}$ generation, being 8 from the Catucaí Group (cross of cultivars Catuaí with coffees of the group of germplasm Icatu-1 to 8 treatment), 10 descendants of "Híbrido de Timor" (Catuaí Vermelho e Catuaí Amarelo with "Híbrido de Timor"--treatment from 9 to 18) and two commercial cultivars resistant to leaf rust as witnesses (Tupi IAC 1669-33 and Obatã IAC 1669-20).

The progenies studied were selected in superior plants cultivated at Fazenda Ouro Verde, located in the municipality of Campos Altos, in the region Cerrado Mineiro, an area with a designation of origin in Minas Gerais, Brazil. The relationship and characterization of progenies/cultivars are presented in Table 1.

Table 1. Relation and characterization of 18 progenies and 2 cultivars used in the experiment conducted at the Federal University of Lavras, Lavras-MG

\begin{tabular}{lll}
\hline $\mathbf{N}^{\mathbf{0}}$ & Identification & Characterization of the progenies/cultivars \\
\hline 1 & Catucaí Vermelho 20/15-MS pl 01 & Dark red fruit, bronze bud. \\
2 & Catucaí Vermelho 20/15-MS pl 02 & Big fruit, smaller canopy diameter, and bronze bud. \\
3 & Catucaí Vermelho 20/15-MS pl 03 & Dark red fruit and open architecture. \\
4 & Catucaí Amarelo 24/137-MS pl 01 & Bronze bud and cylindrical architecture. \\
5 & Catucaí Amarelo 24/137-MS pl 02 & Medium-sized and bronze bud. \\
6 & Catucaí Amarelo 24/137-MS pl 03 & Late maturation and green bud. \\
7 & Catucaí Amarelo 24/137-MS pl 04 & Green bud and smaller canopy diameter. \\
8 & Catucaí Amarelo 24/137-MS pl 05 & Short-sized and intense branching. \\
9 & H516-2-1-1-18-1-1 & Bronze bud and dark red fruit. \\
10 & H516-2-1-1-18-1-2 & Bronze bud, large fruit and little resistance from the stalk. \\
11 & H516-2-1-1-18-1-3 & Late maturation, bronze bud, and medium-sized. \\
12 & H516-2-1-1-18-1-4 & Medium-sized, intense ramification, medium fruit, and bronze bud. \\
13 & H516-2-1-1-18-1-5 & Big fruit, little branched and large leaves. \\
14 & H419-3-4-5-2-1-1 & Green bud and little resistance from the stalk. \\
15 & H419-3-4-5-2-1-2 & Green bud, long branch, large fruit and little resistance from the stalk. \\
16 & H419-3-4-5-2-1-3 & Bronze bud and early maturation. \\
17 & H419-3-4-5-2-1-4 & Bronze bud, red fruit and little resistance from the stalk. \\
18 & H419-3-4-5-2-1-5 & Red fruit and bronze bud. \\
19 & Tupi IAC 1669-33 & Short-sized and dark red fruit. \\
20 & Obatã IAC 1669-20 & Short-sized and uneven maturation. \\
\hline
\end{tabular}


The experimental design utilized was randomized blocks with three replicates, and 20 treatments (18 progenies and 2 commercial cultivars) totaling 60 experimental plots consisting of 15 plants each. The deployment and conduct of the experiment were carried out on the basis of technical recommendations to the coffee culture.

The evaluations of productivity were measured in liters of "coffee per total combing" per plot, annually for six seasons (2008/2009 to 2013/2014) between the months of May to July of each year, with subsequent conversion to bags of $60 \mathrm{~kg}$ of coffee processed $\mathrm{ha}^{-1}$ considering the yield of each genotype. The pruning type 'esqueletamento' was held in August 2014 after the sixth harvest, by removing the terminal part of the plagiotropic branches of the coffee tree, keeping 30 to $40 \mathrm{~cm}$ of the orthotropic. Shortly after it was performed the pruning of the orthotropic branch two meters high from the ground, conducting only a sprouting above the cutoff point.

On the occasion of the first crop after pruning the following characters were evaluated: productivity, mocha, sieve No.16 grains and above, vegetative vigor, the incidence of leaf rust, dull fruits, aspect and quality of the drink. The harvesting was carried out by combing the fruit and picking on cloth, with later weighing in $\mathrm{kg}$ of coffee per combing by installment. Later, four liters of this plot were packed in braided polyethylene bags and taken to dry until they reached $\pm 11.0 \%$ of water content. Then the samples were processed and weighed to estimate the yield of each genotype, but also perform the conversion to bags of $60 \mathrm{~kg}$ of processed coffee.

Comparisons were made with the values of productivity, obtaining a ratio (\%):

(a) between the average productivity of the biennium in the system "zero yield" (productivity after pruning divided by 2) with the average of the yields before pruning;

(b) between productivity after pruning with maximum productivity achieved before pruning.

From the processed coffee, it was adopted a sample of 300 grams (absent of impurities and grain pieces) and performed the granulometric analysis (size and shape of the grains), subjecting the samples by a set of sieves interspersed. The percentage of grain type mocha was given by the sum of the weights of grain held in oblong sieves $(13,12,11,10,09$ and 08/64), as well as the percentage of sieve No.16 and above was given by the sum of grain weight retained on circular sieves (19, 18, 17 and 16/64) (Ministério da Agricultura, Pecuária e Abastecimento, 2003).

The vegetative vigor was evaluated 25 days before harvest, being assigned scores according to an arbitrary scale of 10 points for three calibrated evaluators, where score 1 is given to the worst plants, with low vegetative vigor and sharp depletion, so as the score 10 for extremely vigorous plants, with leaves, high growth of productive branches and high pending load, as suggested by Carvalho et al. (1979).

The incidence of leaf rust was given 20 days before harvest, by sampling, collecting 100 leaves per portion in the middle third of the plants, in the third or fourth pair of leaves from plagiotropic branches. It was determined in percentage $(\%)$ counting the number of leaves with sporulating pustules of the fungus.

The percentage of dull fruits was estimated based on the methodology proposed by Antunes Filho and Carvalho (1954), in which 100 ripe fruits are placed in a container with water, being adopted as "dull" the fruits that remain on the surface.

From the rest of the harvested coffee, seven liters of ripe fruits per plot were selected. These samples were dried on screens with shade cloth, suspended from the terrace until they reach $\pm 11 \%$ water content. Once dry the coffee was stored for 30 days in a cooled environment at $\pm 18{ }^{\circ} \mathrm{C}$ in the Center of Technology in Quality of Coffee at the Universidade Federal of Lavras. After this period the samples were processed and submitted to the other assessments.

To evaluate the aspect of the processed raw grain, it was developed a methodology, where samples are scattered in a black cardboard and evaluated visually by three calibrated evaluators, assigning scores on a scale from 1 to 5 points, where, 1 = grains with uneven appearance, discrepant color, and adhered espermoderm; $2=$ grains with uneven appearance, greenish coloration (typical of natural coffees processed dry) and adhered espermoderm; $3=$ average-looking grain, greenish coloration (typical of natural coffees processed dry) and light presence of adhered espermoderm; 4 = uniform-looking grain, light coloration (typical of coffees processed by the wet method) and light presence of adhered espermoderm, and $5=$ grains with uniform appearance, intense bluish-green without adhered espermoderm.

The sensory evaluation (cupping) was performed in the Laboratories of Classification and Industrialization of Coffee at IFSULDEMINAS Campus Muzambinho, by three judges Q-Graders, calibrated according to the protocol of the Special Coffees Association of America (SCAA), with 5 cups per plot. The standard samples (sieve No.16 and above and absent of flaws) were roasted according to the SCAA, whose coloration indicated 55\# to 65\# 
in the Agtron scale. The attributes fragrance, flavor, acidity, body, aftertaste, balance, uniformity, clean cup, sweetness and over all were evaluated with scores on a scale from 6 to 10 points. The final score was calculated considering the sum of the ten sensory attributes.

For statistical analysis, we used the software 'Sisvar' version 5.6 (Ferreira, 2014), where the data were subjected to analysis of variance (ANOVA) and when detected significant differences in F-test it was applied the Scott-Knott test at $5 \%$ level of probability.

The sensory attributes of coffees have been assessed in a Radar diagram (graphic scale), called "Sensogram", according to the average score of the sensory attributes, comparing the groups of progenies with the witnesses.

\section{Results and Discussion}

To the average productivity before the 'esqueletamento', it is given highlight to the genotypes $1,2,6,14,15,19$ (Tupi IAC 1669-33) and 20 (Obatã IAC 1669-20), with values ranging from 39.5 to 50.5 bags ha $^{-1}$. However, with the first year after the pruning, productivity ranged from 36.8 to $87.6 \mathrm{bags} \mathrm{ha}^{-1}$, with a general average of 67.6 bags $\mathrm{ha}^{-1}$ with the formation of two groups. The group is composed of 14 genotypes with productivities between 64.8 and 87.6 bags ha $^{-1}$. It is worth noting in this group the genotypes 12, 14, 18 and 19 (Tupi IAC 1669-33) that, in addition to high productivity were the most vigorous and showed leaf rust resistance (Tables 2 and 3).

These data are similar to those found by Carvalho et al. (2013), which obtained an average productivity of 70.95 bags $\mathrm{ha}^{-1}$ in the first year after the 'esqueletamento' of progenies of Catuaí Amarelo IAC 2077-1-2-12-70 and Mundo Novo IAC 515-20.

When comparing the average productivity of the biennium in the system "Zero Yield" with the average productivity before pruning it is noted that the genotypes $4,18,9,16,12,17$ and 19 (Tupi IAC 1669-33) showed values of ratios higher than $100 \%$, being responsive to the 'esqueletamento' (Table 2).

These data corroborate with Reis (2016), in which the author also found higher values in response to pruning the cultivars Tupi IAC 1669-33, Catucaí Amarelo 20/15, Araponga MG1 and Acauã. The author even cites that these genotypes would be efficient in "Zero Yield" system, in which the plants are pruned again after harvesting, and possibly would produce little in the following year, due to low vegetative growth, led by the high reproductive development, triggered by the high reproductive development.

Silva et al. (2016) working with a crop of four and a half years of age reported that the studied cultivars showed resilience after 'esqueletamento' in young stage, with emphasis on the cultivars Catigua MG1, Topázio MG1190 and Sabiá 398 which presented high yields allied to a good vigor, low percentage of dull fruits and high percentage of high bolted grains in the first biennium after pruning.

The remaining genotypes presented average productivity of the first biennium after pruning inferior to the average before pruning. These results are in agreement with other authors who say that pruning, in general, doesn't increase productivity (Silva et al., 2016; Fernandes \& Santinato, 2012; Japiassú et al., 2010). However, one must consider the elimination of the costs with the harvesting in alternating years, and this practice has great participation in the final cost of the bag of processed coffee.

It is observed that the genotypes 18, 9, 12,13, 8, 16, 17 and 19 (Tupi IAC 1669-33) presented a productivity after pruning, higher than the maximum achieved before pruning, highlighting the effect of pruning on vegetative recovery and good reproductive development of these materials. 
Table 2. Ratio (\%) between the average productivity of the biennium in the system "Zero Yield" (MBSZ) and the average productivity before pruning (PM) and between the productivity of first year after pruning (PPP) and the maximum productivity achieved before pruning (PMA)

\begin{tabular}{|c|c|c|c|c|c|c|}
\hline Genotypes & PM & MBSZ & RATIO (\%) & PMA & PPP & RATIO (\%) \\
\hline 1 & $47.6 \mathrm{a}$ & $35.7 \mathrm{a}$ & 75 & $90.2 \mathrm{a}$ & $71.3 \mathrm{a}$ & 79 \\
\hline 2 & $41.9 \mathrm{a}$ & $27.1 \mathrm{~b}$ & 65 & $77.6 \mathrm{a}$ & $54.2 \mathrm{~b}$ & 70 \\
\hline 3 & $35.4 \mathrm{~b}$ & $30.2 \mathrm{~b}$ & 85 & $86.4 \mathrm{a}$ & $60.3 \mathrm{~b}$ & 70 \\
\hline 4 & $36.4 \mathrm{~b}$ & $37.7 \mathrm{a}$ & 104 & $79.2 \mathrm{a}$ & $75.4 \mathrm{a}$ & 95 \\
\hline 5 & $37.2 \mathrm{~b}$ & $33.9 \mathrm{a}$ & 91 & $76.2 \mathrm{a}$ & $67.8 \mathrm{a}$ & 89 \\
\hline 6 & $39.5 \mathrm{a}$ & $32.4 \mathrm{a}$ & 82 & $69.3 \mathrm{a}$ & $64.8 \mathrm{a}$ & 94 \\
\hline 7 & $29.9 \mathrm{~b}$ & $28.7 \mathrm{~b}$ & 96 & $58.6 \mathrm{a}$ & $57.3 \mathrm{~b}$ & 98 \\
\hline 8 & $36.3 \mathrm{~b}$ & $34.8 \mathrm{a}$ & 96 & $61.9 \mathrm{a}$ & $69.6 \mathrm{a}$ & 112 \\
\hline 9 & $35.3 \mathrm{~b}$ & $40.8 \mathrm{a}$ & 115 & $75.4 \mathrm{a}$ & $81.5 \mathrm{a}$ & 108 \\
\hline 10 & $37.2 \mathrm{~b}$ & $18.4 \mathrm{~b}$ & 49 & $81.8 \mathrm{a}$ & $36.8 \mathrm{~b}$ & 45 \\
\hline 11 & $35.5 \mathrm{~b}$ & $28.5 \mathrm{~b}$ & 80 & $74.8 \mathrm{a}$ & $57.0 \mathrm{~b}$ & 76 \\
\hline 12 & $32.6 \mathrm{~b}$ & $37.8 \mathrm{a}$ & 116 & $67.8 \mathrm{a}$ & $75.6 \mathrm{a}$ & 112 \\
\hline 13 & $36.1 \mathrm{~b}$ & $34.5 \mathrm{a}$ & 95 & $64.7 \mathrm{a}$ & $68.9 \mathrm{a}$ & 107 \\
\hline 14 & $40.1 \mathrm{a}$ & $38.3 \mathrm{a}$ & 96 & $76.9 \mathrm{a}$ & $76.6 \mathrm{a}$ & 100 \\
\hline 15 & $43.6 \mathrm{a}$ & $34.1 \mathrm{a}$ & 78 & $98.4 \mathrm{a}$ & $68.1 \mathrm{a}$ & 69 \\
\hline 16 & $34.0 \mathrm{~b}$ & $34.3 \mathrm{a}$ & 101 & $61.0 \mathrm{a}$ & $68.5 \mathrm{a}$ & 112 \\
\hline 17 & $24.9 \mathrm{~b}$ & $29.9 \mathrm{~b}$ & 120 & $57.7 \mathrm{a}$ & $59.7 \mathrm{~b}$ & 104 \\
\hline 18 & $36.1 \mathrm{~b}$ & $43.8 \mathrm{a}$ & 121 & $77.1 \mathrm{a}$ & $87.6 \mathrm{a}$ & 114 \\
\hline 19 & $39.5 \mathrm{a}$ & $40.6 \mathrm{a}$ & 103 & $77.3 \mathrm{a}$ & $81.1 \mathrm{a}$ & 105 \\
\hline 20 & $50.5 \mathrm{a}$ & $34.8 \mathrm{a}$ & 69 & $90.4 \mathrm{a}$ & $69.6 \mathrm{a}$ & 77 \\
\hline Means & 37.5 & 33.8 & 92 & 75.1 & 67.6 & 92 \\
\hline CV\% & 14.81 & 17.51 & - & 17.70 & 17.51 & - \\
\hline
\end{tabular}

Note. Means followed by the same letter in the column do not differ significantly by Scott-Knott test at $5 \%$ probability. Coefficient of variation (CV\%).

For vegetative vigor, there was an emphasis on the genotypes 12,14, 18 and 19 (Tupi IAC 1669-33) with an 8.7 to a 9.3 range (Table 3). These results corroborate with Carvalho et al. (2012), which found scores for Catucaí Amarelo 24/137, Catucaí Vermelho 20/15, Araponga MG1, Paraíso MG H419-1, Tupi IAC 1669-33 and Obatã IAC 1669-20 ranging from 7.2 to 8.7, being similar to those identified in this work. Carvalho (2014) found values between 5.8 to 6.7 for the vegetative vigor of the same genotypes under study, before the esqueletamento, showing the effect of pruning on the reinvigoration of the plants.

According to Severino et al. (2002), high vegetative vigor relates positively to the adaptation of the genotype, reflecting on plants less depleted. The genotypes 11, 9, 13, 15, 17, 10 and 20 (Obatã IAC 1669-20) behaved in the range of 7.3 to 8.3 points with a medium vigor (Table 3 ). The other genotypes showed low vegetative vigor, with severe defoliation due to the pending high load and incidence of leaf rust (Table 3). It is worth mentioning that 55\% of genotypes were higher than the general average (7.2).

For leaf rust incidence three groups were formed being the genotypes 12, 14, 18, 11, 13, 15, 10, 19 (Tupi IAC 1669-33) and 20 (Obatã IAC 1669-20) resistant to the disease, in the total absence of symptoms in the leaves (Table 3). All the mentioned genotypes are descendants of "Hibrido de Timor", being that this germplasm has at least the genes of major resistance to the fungus, the SH5, and the SH9 (Bettencourt, Lopes, \& Palma, 1992). Besides the genes already identified, it is likely that other genes are present in these genotypes (Varzea \& Marques, 2005), making greater resistance to the materials from these crossings.

These data are similar to those found by Pereira et al. (2001), who observed satisfactory results in the evaluation of progenies of Catuaí Amarelo with "Híbrido de Timor", with high yield, stability, and high potential to compose cultivars leaf rust resistant. Other authors confirm the leaf rust resistance of materials descendants of "Hibrido de Timor" (Paiva et al., 2010; Reis, 2016).

The second group was composed of genotypes 9 and 17, that showed $31 \%$ incidence of leaf rust on the leaves sampled. According to Botelho et al. (2010), the intermediate incidence of a genotype is interesting because it is 
not possible to select genotypes with horizontal resistance in those absent from the disease, and these probably present resistance of vertical type or specific, covering the manifestation of horizontal resistance. The remaining genotypes varied between $57 \%$ and $74 \%$ of identified leaves with sporulating pustules of the fungus. It is worth mentioning the genotype 16, being the only descendant of the "Hibrido de Timor" with high percentage of leaf rust , being able to be explained by the occurrence of break of resistance of this genotype by some physiological races of the fungus present in the region, where the local environment may have been conducive to this break.

Costa et al. (2007) mentioned that the "Hibrido de Timor" can be used as a source for vertical and/or horizontal resistance in genetic improvement programs, in order to obtain cultivars resistant to leaf rust. Reis (2016) confirms the high incidence of leaf rust in the cultivars Catucaí Amarelo 24/137 (38\%) and Catucaí Vermelho 20/15 (42\%), but still lower than the values found for the genotypes of this study, showing that there is resistance breaking for physiological races of the fungus present in the region.

In relation to the percentage of dull fruits the genotypes were divided into three groups, and the group with lower percentages was composed of 17 genotypes and among them, with the exception of the genotype 13 which presented $11.3 \%$, others showed lower values than the maximum allowable of $10 \%$ (Carvalho et al., 2016) ranging from $3.0 \%$ to $8.7 \%$ of dull fruits (Table 3 ).

The genotypes 9, 17 and 18 showed high percentages of dull fruits, not being interesting to the genetic improvement programs of the coffee trees. These data are similar to those found by Carvalho (2014), which also found high values of dull fruits for the genotypes 9 and 17. According to Carvalho et al. (2006), values close to $90 \%$ of seeded fruits are adopted as satisfactory for the breeders during the evaluation and selection of the coffee tree, whereas most cultivars on the market feature similar percentages.

In addition, the plants may show greater sensitivity to water restrictions, and in the seeding phase the water deficit can lead to the dullness and bad seeding of the fruits (Nascimento, Spehar, \& Sandri, 2014).

Table 3. vegetative vigor (VV), incidence of leaf rust (IF), $\%$ of dull grains $(\mathrm{CH}), \%$ of grain type mocha (MOCA), $\%$ of sieve No. 16 and above (16 and AC), aspect (ASP) and drink.

\begin{tabular}{|c|c|c|c|c|c|c|c|}
\hline Genotypes & VV & IF & $\mathbf{C H}$ & MOCA & $16 \mathrm{EAC}$ & ASP & DRINK \\
\hline 1 & $5.7 \mathrm{c}$ & $70 \mathrm{c}$ & $6.3 \mathrm{a}$ & $18.3 \mathrm{~b}$ & $41.3 \mathrm{~b}$ & $1.7 \mathrm{c}$ & $82.75 \mathrm{a}$ \\
\hline 2 & $5.0 \mathrm{c}$ & $74 \mathrm{c}$ & $8.7 \mathrm{a}$ & $17.3 \mathrm{~b}$ & $24.4 \mathrm{c}$ & $1.0 \mathrm{c}$ & $81.53 \mathrm{a}$ \\
\hline 3 & $6.0 \mathrm{c}$ & $59 \mathrm{c}$ & $8.7 \mathrm{a}$ & $17.4 \mathrm{~b}$ & $40.2 \mathrm{~b}$ & $1.7 \mathrm{c}$ & $81.04 \mathrm{a}$ \\
\hline 4 & $6.0 \mathrm{c}$ & $60 \mathrm{c}$ & $3.0 \mathrm{a}$ & $9.4 \mathrm{a}$ & $58.6 \mathrm{a}$ & $2.7 \mathrm{~b}$ & $77.03 \mathrm{~b}$ \\
\hline 5 & $5.7 \mathrm{c}$ & $65 \mathrm{c}$ & $8.0 \mathrm{a}$ & $12.9 \mathrm{a}$ & $61.1 \mathrm{a}$ & $1.3 \mathrm{c}$ & $78.08 \mathrm{~b}$ \\
\hline 6 & $6.0 \mathrm{c}$ & $57 \mathrm{c}$ & $7.7 \mathrm{a}$ & $9.9 \mathrm{a}$ & $68.3 \mathrm{a}$ & $2.0 \mathrm{c}$ & $77.11 \mathrm{~b}$ \\
\hline 7 & $5.7 \mathrm{c}$ & $64 \mathrm{c}$ & $4.3 \mathrm{a}$ & $9.3 \mathrm{a}$ & $65.8 \mathrm{a}$ & $3.0 \mathrm{~b}$ & $75.37 b$ \\
\hline 8 & $7.0 \mathrm{c}$ & $62 \mathrm{c}$ & $8.0 \mathrm{a}$ & $16.4 \mathrm{~b}$ & $50.5 \mathrm{~b}$ & $2.0 \mathrm{c}$ & $79.38 \mathrm{~b}$ \\
\hline 9 & $8.0 \mathrm{~b}$ & $31 \mathrm{~b}$ & $26.7 \mathrm{c}$ & $15.2 \mathrm{~b}$ & $60.6 \mathrm{a}$ & $3.0 \mathrm{~b}$ & $83.03 \mathrm{a}$ \\
\hline 10 & $7.7 \mathrm{~b}$ & $0 \mathrm{a}$ & $4.0 \mathrm{a}$ & $10.7 \mathrm{a}$ & $63.9 \mathrm{a}$ & $5.0 \mathrm{a}$ & $82.83 \mathrm{a}$ \\
\hline 11 & $8.3 \mathrm{~b}$ & $0 \mathrm{a}$ & $5.0 \mathrm{a}$ & $13.4 \mathrm{a}$ & $72.2 \mathrm{a}$ & $5.0 \mathrm{a}$ & $84.45 \mathrm{a}$ \\
\hline 12 & $9.3 \mathrm{a}$ & $0 \mathrm{a}$ & $6.7 \mathrm{a}$ & $13.3 \mathrm{a}$ & $57.8 \mathrm{a}$ & $4.3 \mathrm{a}$ & $83.57 \mathrm{a}$ \\
\hline 13 & $8.0 \mathrm{~b}$ & $0 \mathrm{a}$ & $11.3 \mathrm{a}$ & $13.2 \mathrm{a}$ & $65.4 \mathrm{a}$ & $4.7 \mathrm{a}$ & $84.25 \mathrm{a}$ \\
\hline 14 & $9.0 \mathrm{a}$ & $0 \mathrm{a}$ & $6.7 \mathrm{a}$ & $13.2 \mathrm{a}$ & $69.0 \mathrm{a}$ & $2.7 \mathrm{~b}$ & $82.72 \mathrm{a}$ \\
\hline 15 & $7.7 \mathrm{~b}$ & $0 \mathrm{a}$ & $8.0 \mathrm{a}$ & $10.9 \mathrm{a}$ & $71.8 \mathrm{a}$ & $3.3 \mathrm{~b}$ & $85.39 \mathrm{a}$ \\
\hline 16 & $7.0 \mathrm{c}$ & $58 \mathrm{c}$ & $5.7 \mathrm{a}$ & $11.0 \mathrm{a}$ & $61.2 \mathrm{a}$ & $2.7 \mathrm{~b}$ & $81.31 \mathrm{a}$ \\
\hline 17 & $7.7 \mathrm{~b}$ & $31 \mathrm{~b}$ & $32.0 \mathrm{c}$ & $18.8 \mathrm{~b}$ & $66.3 \mathrm{a}$ & $2.3 \mathrm{~b}$ & $82.83 \mathrm{a}$ \\
\hline 18 & $9.0 \mathrm{a}$ & $0 \mathrm{a}$ & $19.7 \mathrm{~b}$ & $12.6 \mathrm{a}$ & $70.5 \mathrm{a}$ & $3.0 \mathrm{~b}$ & $82.54 \mathrm{a}$ \\
\hline 19 & $8.7 \mathrm{a}$ & $0 \mathrm{a}$ & $7.0 \mathrm{a}$ & $13.8 \mathrm{a}$ & $61.7 \mathrm{a}$ & $3.0 \mathrm{~b}$ & $83.86 \mathrm{a}$ \\
\hline 20 & $7.3 \mathrm{~b}$ & $0 \mathrm{a}$ & $4.3 \mathrm{a}$ & $13.4 \mathrm{a}$ & $49.2 \mathrm{~b}$ & $3.0 \mathrm{~b}$ & $86.64 \mathrm{a}$ \\
\hline Means & 7.2 & 32 & 9.6 & 13.5 & 59 & 2.9 & 81.79 \\
\hline CV\% & 10.74 & 30.12 & 47.21 & 17.74 & 13.13 & 21.5 & 2.13 \\
\hline
\end{tabular}

Note. Means followed by the same letter in the column do not differ significantly by Scott-Knott test at $5 \%$ probability. Coefficient of variation (CV\%). 
When considering the percentage of grains of type mocha, note that there was the formation of two groups. It is observed that the genotypes 7, 4, 6, 5, 10, 11, 12, 13, 15, 16, 18, 14, 20 (Obatã IAC 1669-20) and 19 (Tupi IAC 1669-33) showed smaller percentages of grain type mocha ranging from 9.3 to $13.8 \%$ (Table 3 ), and $50 \%$ of them are within the maximum permitted threshold. In the production of certified seeds of coffee, the standardization criteria indicate a maximum tolerance of $12 \%$ of seed type mocha (Paiva et al.., 2010; Carvalho et al., 2013). The genotypes $1,2,3,8,9$ and 17 showed high percentages of grains like mocha ranging from $15.2 \%$ to $18.8 \%$. This type of grain can also be associated with adverse environmental factors, such as high temperatures at flowering or early fruiting (Pezzopane et al., 2007).

Although not considered a physical defect by physical classification methodology, the grain type mocha is considered a defect to the breeders of the coffee tree, due to the formation of only one seed in the fruit, which refers to a poor yield in the processed coffee. In a work done by Silva et al. (2016), it was evidenced that the pruning has not contributed to the increase in the percentage of grains of type mocha.

However, in relation to the percentage of sieve No. 16 and above the formation of three groups, being the top group composed of 15 genotypes, ranging from $57.8 \%$ to $72.2 \%$ of sieve No. and above (Table 3 ). These values are normal and similar to those found by Carvalho et al. (2012), who observed percentages of sieve No.16 and above in the range of $51.0 \%$ to $68.7 \%$. High percentages of large grains show a greater potential for adding value in the commercialization of coffee, in addition, indicate good conditions of nutritional and sanitary management at all stages of formation of the fruits.

In the process of evaluation and selection of coffee trees, it is sought an ideotype whose performance of materials cover various characteristics, including high yields as well as a high percentage of retained grain in large sieves (Ferreira et al., 2005). According to Ferreira et al. (2013), as the size of the grains grow, more uniform is the batch to be processed, influencing directly the physical aspect of the product, being desirable in espresso machines for example, where the roasted beans are exposed to the consumer.

According to Silva et al. (2016), the variation of grain size is not affected by the esqueletamento but mainly by climatic conditions at the place of conduction of the experiment.

To the aspect there was the formation of three groups, being the upper group composed of the genotypes $11,10,13$ and 12 showing a better aspect of the processed raw grains, with scores 5.0, 5.0, 4.7 and 4.3, respectively (Table 3), since these samples showed a bluish green colour, absence of spermoderm adhered to the grains and uniformity among themselves.

The second group was composed of 10 genotypes with scores ranging from 2.3 to 3.3 , as well as the third group with 6 genotypes with scores ranging from 1.0 to 2.0. The latter genotypes showed an undesirable aspect of yellow and uneven color, with intense presence of spermoderm adhered to the grains.

In regard to the quality of drink two groups were formed, being the top group composed of 15 genotypes with final sensory scores ranging from 81.04 to 86.64 points according to the SCAA Protocol (Table 3 ). The sensory analysis of the SCAA methodology adopts as specialty coffees those with scores greater than or equal to 80 points, so all of these genotypes showed potential in the production of specialty coffees. However, the genotypes 15 and 20 (Obatã IAC 1669-20) presented the scores 85.39 and 86.64 , respectively, being classified as excellent.

These results agree with those found by Sobreira et al. (2015), which claim that descendants of "Hibrido de Timor" have high potential in the production of specialty coffees, with averages higher than Bourbon, Caturra, and traditional cultivars. Other authors also observed similar results for progenies and cultivars derived from "Hibrido de Timor" (Chalfoun et al., 2013).

The second group was composed only by genotypes of Catucaí Amarelo 24/137 (4, 5, 6, 7, and 8), with scores ranging from 75.36 to 79.38 points. According to the Protocol of the SCAA, the coffees with scores of 75 to 79 are classified as normal good quality coffees. It is worth mentioning that even with lower notes none of the genotypes showed sensory defects in the cup, once applied postharvest management practices.

The fact that no genotype has presented sensory defect, all five cups evaluated in each plot were adopted as clean, with the presence of sweetness and uniformity among themselves, making these three attributes to obtain the maximum score (10 points). To the seven other attributes, it should be noted that only the progenies of Catucaí Amarelo 24/137 obtained scores of less than 7 points, which explains the fact of these progenies presented lower final scores (Figure 1). 


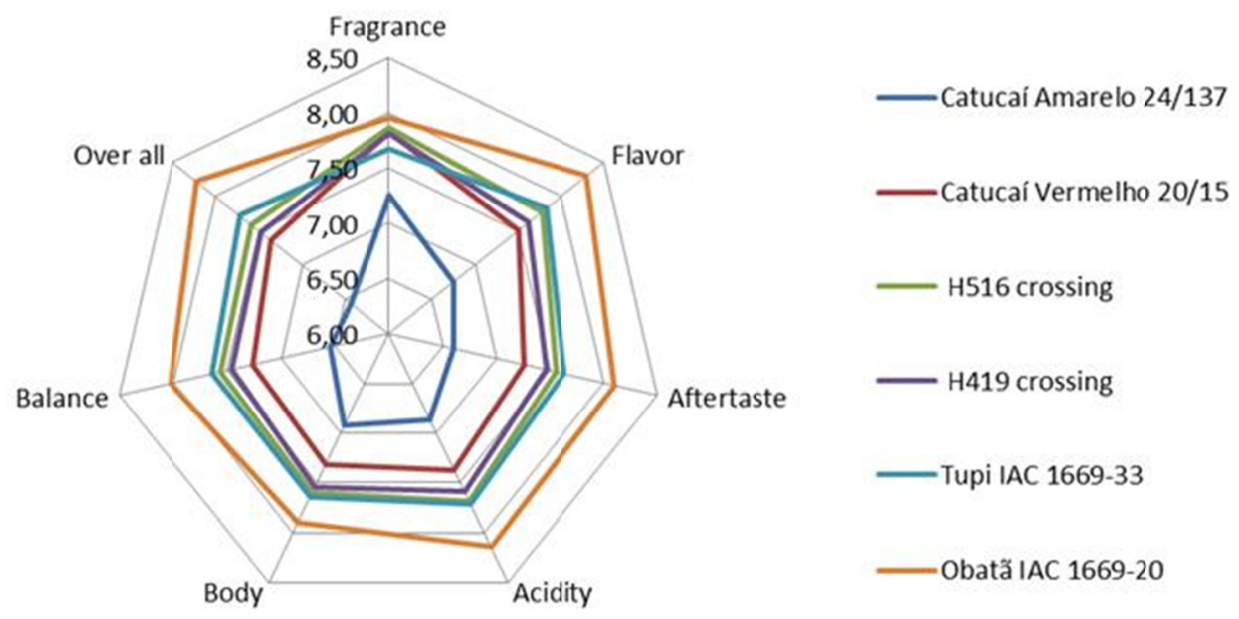

Figure 1. Sensogram with the means of the sensory attributes of the progenies of Catucaí Amarelo 24/137, Catucaí Vermelho 20/15, H516 crossing, H419 crossing, and the witnesses Tupi IAC 1669-33 and Obatã IAC 1669-20

The Figure 1 allows the visualization of the means of the attributes for each group of genotypes compared to two witnesses, highlighting the genotype 20 (Obatã IAC 1669-20) which presented greater potential in the production of specialty coffees, such as the group of genotypes of Catucaí Amarelo 24/137 that distanced themselves more in all attributes of other genotypes under study, but in a negative way.

According to Setotaw et al. (2013), the cultivars derived from the "Hibrido de Timor" have on average, about 11\% of genotypic contribution of "Hibrido de Timor". This relationship may indicate that this germplasm has great participation for the improvement of the quality of drink of cultivars derived from "Hibrido de Timor" with emphasis on the flavor attribute. According to Agwanda et al. (2003), this attribute stands out as one of the main criteria in sensory quality gains.

\section{Conclusion}

The genotypes 9 (H516-2-1-1-18-1-1), 12 (H516-2-1-1-18-1-4), 16 (H419-3-4-5-2-1-3), 18 (H419-3-4-5-2-1-5) and 19 (Tupi IAC 1669-33) were responsive to 'esqueletamento', with productivity after pruning higher than the maximum reached before the adoption of the pruning, as also featuring an average productivity in the biennium in the system "Zero Yield" higher than the average productivity before pruning.

The genotypes 15 (H419-3-4-5-2-1-2) and 20 (Obatã IAC 1669-20) have a drink is classified as excellent.

\section{References}

Agwanda, C. O., Baradat, P., Eskes, A. B., Cilas, C., \& Charrier, A. (2003). Selection for bean and liquor qualities within related hybrids of Arabica coffee in multi-local field trials. Euphytica, 131, 1-14. https://doi.org/10.1023/A:1023071815109

Antunes Filho, H., \& Carvalho, A. (1954). Melhoramento do cafeeiro, ocorrência de lojas vazias em frutos de café Mundo Novo. Bragantia, 13(14), 165-179. https://doi.org/10.1590/S0006-87051954000100014

Bettencourt, A. J., Lopes, J., \& Palma, S. (1992). Fatores genéticos que condicionam a resistência às raças de Hemileia vastatrix Berk. et Br. dos clones-tipo dos grupos 1, 2 e 3 de derivados de Híbrido de Timor. Brotéria Genética, 13(80), 185-194.

Botelho, C. E., Mendes, A. N. G., Carvalho, G. R., Bartholo, G. F., \& Carvalho, S. P. (2010). Seleção de progênies F4 de cafeeiro obtidas pelo cruzamento de Icatu com Catimor. Revista Ceres, 57(3), 274-281. https://doi.org/10.1590/S0034-737X2010000300010

Carvalho, A. M., Mendes, A. N. G., Botelho, C. E., Oliveira, A. C. B., Rezende, J. C., \& Rezende, R. M. (2012). Desempenho agronômico de cultivares de café resistentes à ferrugem no Estado de Minas Gerais, Brasil. Bragantia, 71(4), 481-487. https://doi.org/10.1590/S0006-87052013005000007

Carvalho, A. M., Rezende, F. V., Botelho, C. E., Carvalho, G. R., \& Ferreira, A. D. (2016). Seleção de progênies de cafeeiros do grupo Catuaí. Coffee Science, 11(2), 244-254. https://doi.org/10.25186/cs.v11i2.1081 
Carvalho, A., Mônaco, L. C., \& Fazuoli, L. C. (1979). Melhoramento do cafeeiro XL: Estudos de progênies e híbridos de café Catuaí. Bragantia, 38(22), 202-216. https://doi.org/10.1590/S0006-87051979000100022

Carvalho, G. R., Bartholo, G. F., Mendes, A. N. G., Nogueira, A. M., \& Magalhaes, M. M. (2006). Seleção de progênies oriundas do cruzamento entre 'Catuaí' e 'Mundo Novo' em diferentes regiões do Estado de Minas Gerais. Bragantia, 65(4), 583-590.. https://doi.org/10.1590/S0006-87052006000400008

Carvalho, G. R., Botelho, C. E., Rezende, J. C. de, Ferreira, A. D., Cunha, R. L. da, \& Pedro, F. C. (2013). Comportamento de progênies F4 de cafeeiros arábica, antes e após a poda tipo esqueletamento. Coffee Science, 8(1), 33-42. https://doi.org/10.25186/cs.v8i1.323

Carvalho, G. R., Rezende, J. C., Botelho, C. E., Ferreira, A. D., Pereira, A. A., \& Oliveira, A. C. B. (2011). Melhoramento genético do café visando à qualidade de bebida. Informe Agropecuário, 32(261), 30-38.

Carvalho, J. P. F. (2014). Seleção de progênies de cafeeiro oriundas da hibridação de cultivares Catuaí com germoplasma Icatu e Híbrido de Timor (83 f. Tese, Doutorado em Agronomia/Fitotecnia, Universidade Federal de Lavras, Lavras, Brazil).

Chalfoun, S. M., Pereira, M. C., Carvalho, G. R., Pereira, A. A., Savian, T. V., \& dos S. Botelho, D. M. (2013). Sensorial characteristics of coffee (Coffea arabica L.) varieties in the alto paranaíba region. Coffee Science, 8(1), 43-52. https://doi.org/10.25186/cs.v8i1.330

Costa, M. J. N., Zambolim, L., Caixeta, E. T., \& Pereira, A. A. (2007). Resistência de progênies de café Catimor à ferrugem. Fitopatologia Brasileira, 32(2), 121-130. https://doi.org/10.1590/S0100-41582007000200005

Fernandes, A. L. T., \& Santinato, F. (2012). Condução das podas do cafeeiro irrigado por gotejamento cultivado no cerrado de Minas Gerais. Enciclopédia Biosfera, Centro Cientifico Conhecer, 8(15), 487-494.

Ferreira, A. D., Carvalho, G. R., Rezende, J. C. de, Botelho, C. E., Rezende, R. M., \& Carvalho, A. M. de. (2013). Desempenho agronômico de seleções de café Bourbon Vermelho e Bourbon Amarelo de diferentes origens. Pesquisa Agropecuária Brasileira, 48(4), 388-394. https://doi.org/10.1590/S0100-204X2013000400006

Ferreira, A. D., Cecon, P. R., Cruz, C. D., Ferrão, R. G., Silva, M. F., Fonseca, A. F. A., \& Ferrão, M. A. G. (2005). Seleção simultânea de Coffea canephora por meio da combinação de análises de fatores e índices de seleção. Pesquisa Agropecuária Brasileira, 40(12), 1189-1195. https://doi.org/10.1590/S0100-204X2005 001200005

Ferreira, A. D., Mendes, A. N. G., Carvalho, G. R., Botelho, C. E., Gonçalves, F. M. A., \& Malta, M. R. (2012). Análise sensorial de diferentes genótipos de cafeeiros bourbon. Interciencia, 37(5), 390-394.

Giomo, G. S., \& Borém, F. M. (2011). Cafés especiais no Brasil: Opção pela qualidade. Informe Agropecuário, Belo Horizonte, 32(261), 7-16.

INMET (National Institute of Meteorology). (2017). BDMEP dados históricos. Retrieved from http://www.inmet.gov.br/portal

Japiassú, L. B., Garcia, A. L. A., Guimarães, R. J., Padilha, L., \& Carvalho, C. H. S. (2010). Ciclos de poda e adubação Nitrogenada em lavouras cafeeiras conduzidas no sistema "safra zero". Coffee Science, 5(1), 28-37. https://doi.org/10.25186/cs.v5i1.269

Ministério da Agricultura, Pecuária e Abastecimento. (2003). Instrução Normativa $n^{\circ} 8$, de 11 de Junho de 2003 (pp. 22-29). República Federativa do Brasil, Brasília.

Nascimento, L., Spehar, C., \& Sandri, D. (2014). Produtividade de cafeeiro orgânico no cerrado após a poda sob diferentes regimes hídricos. Coffee Science, 9(3), 354-365. https://doi.org/10.25186/cs.v9i3.644

Paiva, R. N., Almeida, S. R. D., Matiello, J. B., \& Ferreira, R. A. (2010). Comportamento agronômico de progênies de cafeeiro (Coffea arabica L.) em Varginha-MG. Coffee Science, 5(1), 49-58, https://doi.org/ $10.25186 /$ cs.v5i1.271

Pereira, A. A. Moura, W. M., Bartholo, G. F., Sakiyama, N. S., Zambolim, L., Kochem, M. G., \& Amaral, M. A. (2001). Comportamento de progê-nies resultantes de cruzamentos de catuaí Amarelo com Híbridode Tímor, na Região de São Sebastião do Paraíso, Sul de Minas Gerais (pp. 1312-1318). $2^{\circ}$ Simpósio de Pesquisa Cafes do Brasil, Vitória. Resumos Expandidos, Embrapa/MINASPLAN.

Pezzopane, J. R. M., Pedro Júnior, M. J., Gallo, P. B., Camargo, M. B. P., \& Fazuoli, L. C. (2007). Avaliações fenológicas e agronômicas em café arábica cultivado a pleno sol e consorciado com banana prata anã. Bragantia, 66(4), 527-533. https://doi.org/10.1590/S0006-87052007000400021 
Reis, E. A. C. (2016). Caracterização de cultivares de cafeeiros resistentes à ferrugem submetidas à poda tipo esqueletamento (74 f. Dissertação, Mestrado em Agronomia/Fitotecnia, Universidade Federal de Lavras, Lavras, Brazil).

Setotaw T. A., Caixeta, E. T., Pereira, A. A., Oliveira, A. C. B. de, Cruz, C. D., Zambolim, E. M., ... Sakiyama, N. S. (2013). Coefficient of parentage in Coffea Arabica L. cultivars grown in Brazil. Crop Science, 53, 1237-1247. https://doi.org/10.2135/cropsci2012.09.0541

Severino, L. S., Sakiyama, N. S., Pereira, A. A., Miranda, G. V., Zambolim, L., \& Barros, U. V. (2002). Eficiência dos descritores de cafeeiros (Coffea arabica L.) na discriminação de linhagens de "Catimor". Acta Scientiarum, 24(5), 1487-1492. https://doi.org/10.4025/actasciagron.v24i0.2410

Silva, V., Rezende, J., Carvalho, A. M., Carvalho, G. R., Rezende, T. T., \& Ferreira, A. D. (2016). Recuperação de cultivares de café submetidas ao esqueletamento aos quatro anos e meio de idade. Coffee Science, 11(1), 55-64. https://doi.org/10.25186/cs.v11i1.968

Sobreira, F. M., Oliveira, B., Carlos, A., Antonio, A. P., Milene Francisca, C. S., \& Ney Sussumu, S. (2015). Sensory quality of arabica coffee (Coffea arabica) genealogic groups using the sensorgram and content analysis. Australian Journal of Crop Science, 9(6), 486-493.

Varzea, V. M. P., \& Marques, D. V. (2005). Population variability of Hemileia vastatrix vs. coffee durable resistance. In L. Zambolim, E. M. Zambolim, \& V. M. P. Várzea (Eds.), Durable resistance to coffee lea frust (pp. 53-74). Viçosa, MG: Editora da UFV.

\section{Copyrights}

Copyright for this article is retained by the author(s), with first publication rights granted to the journal.

This is an open-access article distributed under the terms and conditions of the Creative Commons Attribution license (http://creativecommons.org/licenses/by/4.0/). 